\title{
$\operatorname{CoN} F-840408 \cdots-11$
}

CONE $-840408--11$

NOTICE

DE84 011643

PORTIONS OF THIS REPORT ARE ILLEGIBLE. II has been reproduced from the best available copy to permit the broadest possible avail. inility.

\section{NONDESTRUCTIVE LOW-ENERGY PHOTON ANALYSIS OF ENVIRONMENTAL SAMPLES}

Ingvar L. Larsen, Norman H. Cutshall, and Curtis R. Olsen Environmental Sciences Division, Oak Ridge National Laboratory Oak Ridge, Tennessee 37831

\section{DISCLAIMER}

This report was prepared as an account of work sponsored by an agency of the United States Government. Neither the United States Government nor any agency thereof, nor any of their employees, makes any warranty, express or implied, or assumes any legal liability or responsibility for the accuracy, completeness, or usefulness of any information, apparatus, product. or process disclosed, or represents that its use would not infringe privately owned rights. Reference herein to any specific commercial product, process, or service by trade name, trademark, manufacturer, or otherwise does not necessarily constitute or imply its endorsement, recommendation, or favoring by the United States Government or any agency thereor. The views and opinions of authors expressed herein do not necessarily state or reflect those of the United States Government or any agency thereol. 
Low-energy photons that accompany the decay of alphaor beta-emitting radionuclides (e.9., $24 \mathrm{Am}, 210 \mathrm{~Pb}$, and $238 \mathrm{U}-234 \mathrm{Th}$ ) may be used to quantify concentrations of these radionuclides in environmental samples. Previous attempts to quantify these low-energy photons have had limited siccess because of the uncertainty associated with photon attenuation in samples of variable matrix composition. A method for directly measuring and applying the self-absorption correction factor is presented. Results obtained by this nondestructive technique for counting low-energy photons are in agreement with values obtained from intracalibrated samples using radiochemical separations and alpha or beta analysis.

\section{INTRODUCTION}

The analysis of radionuclides in soils and sediments that lack high-energy gamma emissions usially requires chemical leaching, dissolution, and purification, followed by alpha or beta counting. These methods, however, are time consuming, require the attention of skilled technicians, and may produce uncertain or low recoveries, requiring the addition of yield tracers. In some radiochemical separation schemes, incomplete purification may result in interferences by other radionuclides during alpha analysis $(1,2)$.

Many of these radionuclides (e.g., $210 \mathrm{pb}, 241_{\mathrm{Am}}$, and $238_{U-234} \mathrm{Th}$ ) emit low energy photons, either $\mathrm{X}$ rays or gamma rays during alpha or beta decay. Attempts to quantitatively. measure these photon-emission rates, however, has had only limited success because of the uncertainty regarding photon attenuation due to variability in sample matrix composition. In such cases, standards must be fabricated in the same matrix in order to properly compensate for photon attenuation (3).

In order to avoid the need for chemical treatment and to minimize the use of yield tracers, we have applied a teclinique for direct, nondestructive photon counting of environmental samples by measuring the self-absorption directly and applying an appropriate correction factor $(4-6)$.

\section{EXPERTMENTAL}

Samples are packed (either wet or dry) into containers of standard geometry and placed on an intrinsic germanium planar detecior having a thin beryllium entrance window. A disk-mounted radioactive source of the photon energy of interest is then placed on top of the sample container and counted for a short interval (120 to $800 \mathrm{~s})$, to determine 
the count rate for the source attenuated by the sample. The source is then removed, and the sample is counted for a longer time period $(600$ to $150,000 \mathrm{~s})$ in order to achieve a good statistical count rate for the photon of interest in the sample. Corrections were made for any background interferences (7).

The true photon count rate of the sample can be calculated from the self-absorption equation,

$$
I=I_{0} \frac{\left(I-e^{-\mu \rho x}\right)}{\mu \rho x},
$$

where $I_{0}$ and I represent the true and apparent (measured) photon-emission rates, respectively; $\mu$ is the attenuation coefficient $\left(\mathrm{cm}^{2} / \mathrm{g}\right) ; \rho$ is the material density $\left(\mathrm{g} / \mathrm{cm}^{3}\right)$; and $x$ is the path length $(\mathrm{cm})$. The parameterized quantity $\mu \rho x$ is evaluated by counting the disk source on top of an empty sample container and relating it to the initial source count attenuated by the sample and corrected for the sample contribution by

$$
\frac{T}{P}=e^{-\mu \rho x},
$$

where $P$ and $T$ are the unattenuated and attenuated photon intensities, respectively, froln the source.

Substituting $\mathrm{Eg}$. (2) into $\mathrm{Eq}$. (1) and rearranging gives

$$
\frac{I_{0}}{I}=\frac{\ln (P / T)}{I-(T / P)}
$$

which, when multiplied by the measured sample count rate (I), yields the unattenuated sample count rate $\left(I_{0}\right)$.

\section{RESULTS AND DISCUSSION}

\section{$\underline{\text { Lead }-210}$}

We have applied this direct counting technique to the measurement of $210 \mathrm{~Pb}$ in sediment samples and compared our results with those obtained by analyzing the samples using conventional chemical leaching, dissolution, and purification techniques, followed either by alpha or beta counting. Figure 1 illustrates the results of this comparison. Virtually all values from 0 to $10 \mathrm{pCi} / \mathrm{g}$ fall along the line of equivalence. Good agreement also exists for samples with higher concentrations $(10-50 \mathrm{p} / \mathrm{Ci} / \mathrm{g})$, although several samples (from one analyst) lie above the line of equivalence, implying that our technique detects more $210 \mathrm{pb}$ in the sample than methods involving chemical leaching. This discrepancy may reflect either differences 


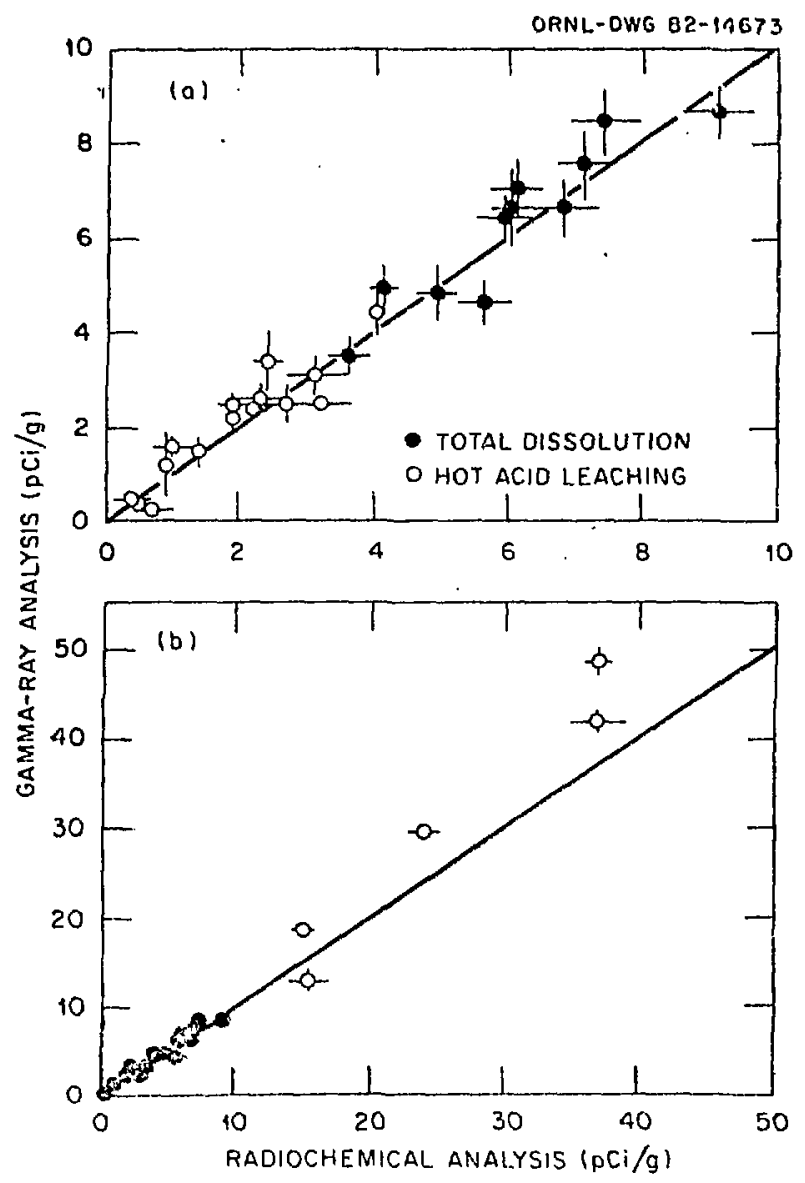

Fig. 1. Plots of results for $210 \mathrm{pb}$ analysis by gamma-ray counting vs. radiochemical procedures; (a) concentration range 0-10 pCi/g. (b) concentration range $0-50 \mathrm{pCi} / \mathrm{g}$. Error bars indicate lo counting errors.

in calibration standards or incomplete $210 \mathrm{pb}$ removal during leaching. Comparisons with standard reference materials (Table I) indicate accuracies up to $75 \mathrm{pCi} / \mathrm{g}$ using our photon counting technique.

\section{Amercium-241}

Comparisons between $24 I_{\text {Am }}$ analyses by photon counting and by radiochemical separation and alpha spectrometry (Table II) cover approximately five orders of magnitude in 241 Am concentrations. Good agreement is apparent within the overall error terms. Small discrepancies are attributed to inhomogeneity of the samples. 
Table $\mathrm{x}$. Comparison of results of $210_{\mathrm{Pb}}$ analysis with expected value of certified reference materials ( 11 (o)

\begin{tabular}{|c|c|c|c|c|c|c|c|}
\hline \multirow{2}{*}{$\begin{array}{l}\text { Material } \\
\begin{array}{c}\text { EPA/NBS Mancos } \\
\text { shale }\end{array}\end{array}$} & \multirow{2}{*}{$\frac{\text { Radionuclide }}{226_{\mathrm{Ra}}}$} & \multicolumn{3}{|c|}{$\begin{array}{c}\text { Certified } \\
\text { value } \\
\text { (pci/g) }\end{array}$} & \multicolumn{3}{|c|}{$\begin{array}{c}210_{\mathrm{Pb}} \\
\text { determined } \\
\text { value } \\
(\mathrm{pCi} / \mathrm{g})\end{array}$} \\
\hline & & 1.55 & \pm & 0.05 & 1.48 & \pm & 0.06 \\
\hline $\begin{array}{l}\text { EPA/NBS Ely ash } \\
\text { NBL } 76-\mathrm{B}\end{array}$ & $226_{\mathrm{Ra}}$ & 3.51 & - & 0.05 & 3.69 & \pm & 0.15 \\
\hline $\begin{array}{l}\text { uranium ore } \\
\text { Canadian }\end{array}$ & ${ }^{22.6} \mathrm{Ra}$ & 33.7 & \pm & 0.3 & 32.1 & \pm & 1.5 \\
\hline $\begin{array}{l}\text { uranium ore } \mathrm{DL}-1 \\
\text { Canadian }\end{array}$ & $210_{\mathrm{Pb}}$ & 13.6 & \pm & 0.4 & 14.4 & \pm & 0.9 \\
\hline $\begin{array}{l}\text { uranium ore } B L-1 \\
\text { EPA/NRC inter- }\end{array}$ & $226_{\mathrm{Ra}}$ & 75.0 & \pm & 2.0 & 75.4 & \pm & 2.7 \\
\hline comparison soil & $210 \mathrm{~Pb}$ & 5.2 & \pm & 1.3 & 5.3 & \pm & 0.2 \\
\hline
\end{tabular}

\footnotetext{
aEPA $=$ Environmental Protection Agency

NBL = New Brunswick Tuaboratory

NBS = National. Bureau of Standards

NRC = Nuclear Regulatory Commissjon
}

Table II. Comparison between photon counting and radiochemical separation and alpha spectrometry of

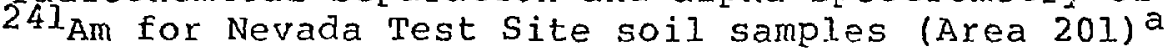

Sample code A

$\begin{array}{lr}\text { A } & 5.07 \\ \text { B } & 10.46 \\ \text { C } & 5.42 \\ \text { D } & 8.74 \\ \text { E } & 5.40 \\ \text { F } & 9.00 \\ \text { G } & 4.92 \\ \text { H } & 10.38\end{array}$

a Note that \pm values indicates $1 \sigma$. For photon counting, this represents the pooled uncertainties based on counting statistics, transmission measurements, and precision and accuracy of the standard. For radiochemical separation and alpha counting of the Nevada Test Site soil samples, this represents counting statistics and yield recovery uncertainties only. 
Table III compares the analytical results obtained for $24 . \mathrm{Am}$ in an International Atomic Lnergy Agency (IAEA) marine sediment sample (SD-B-3) used in a round-robin intercomparison study by the U.S. Department of Energy Our results, obtained by direct photon counting, agree $(8)$. with the $241_{\mathrm{Am}}$ concentrations determinated by other participating laboratories using radiochemical procedures and alpha spectrometry.

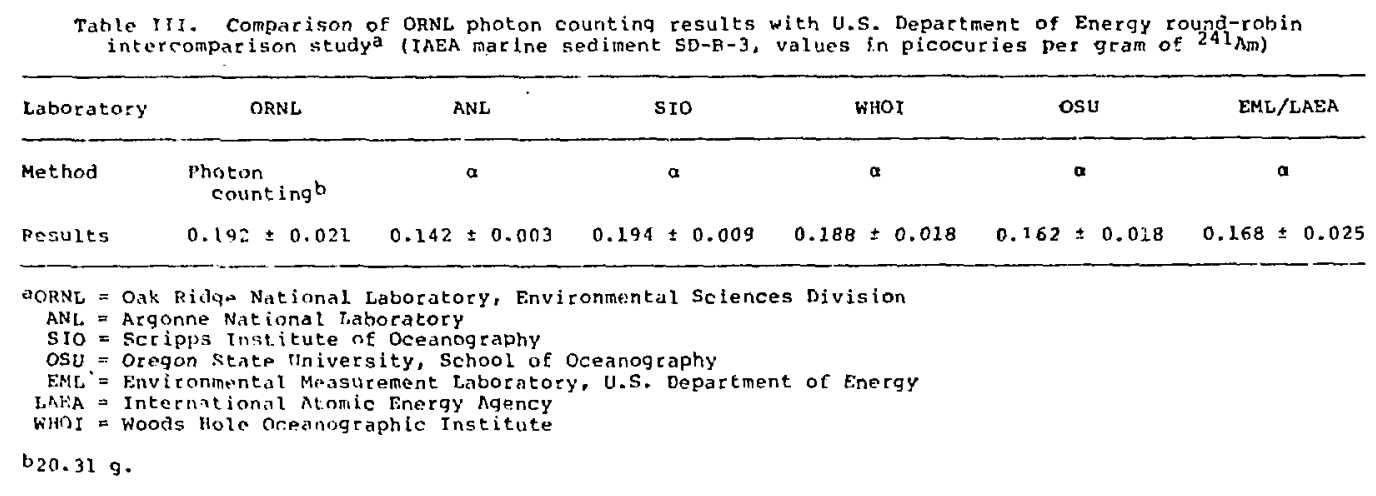

\section{Uranium-238, Thorium-234}

Our photon counting technique was also applied to determine the $238_{\mathrm{U}}$ concentration in an Environmental Protection Agency/Nuclear Regulatory Commission (EPA/NRC) soil sample by measuring the 63.3 -kev photon associated with the $24-3$ half-life daughter $234 \mathrm{Th}$. The measured value, $2.2 \pm 0.2 \mathrm{pCi} / \mathrm{g}$, was in excelient agreemert with the expecied value of $2.4 \pm 0.3 \mathrm{pCi} / \mathrm{g}$.

\section{SUMMARY}

Low-energy photons that accompany the decay of alpha or heta particles may be used to determine concentrations of certain desired radionuclides, thereby eliminating the need for chemical dissolution or extraction, purification, and the addition of tracers to ascertain yield recoveries. The nondestructive gamma spectrometric technique utilizing self-absorption correction methods is rapid, relatively simple, and provides accuracies comparable to conventional inalytical separation techniques. The cost of the required equipment can be compared to the equivalent labor costs involved in preparing approximately 300 samples for beta or alpha spectrometry (5).

\section{ACKNOWLEDGEMENTS}

Research sponsored by the office of Health and Environmental Research, U.S. Department of Energy, under contract W-7405-eng-26 with Union Carbide Corporation. Publication No. 2316, Environmental Sciences Division, ORNL. 
By acceptance of this article, the publisher or recipient acknowledges the U.S. Government's right to retain a nonexclusive, royalty-free license in and to any copyright covering the article.

\section{REFERENCES}

1. Holm, E., Fukai, R., Talanta 24, 659-664 (1977).

2. Carpenter, R., Beasley, T. M., Geochim. Cosmo Acta 45 , 1917-1930 (1978).

3. Crowell, J. M., IEE Trans. Nucl. Sci. NS-28, 282-289 (1978).

4. Chouak, A., Vuister, P., Paic, G., Berrada, M., Csikai, J., J. Radioanal. Chem. 45, 445-451 (1978).

5. Cutshall, N. H., Larsen, I. L., Olsen, C. R., Nucl. Inst.r. Methods 206, 309-312 (1983).

6.. Larsen, I. I., Lee, S. X., J. Radioanal. Chein. 79, 165-169 (1983).

7. Cutshall, N. H., Larsen, I. L., Nucl. Tnstr. Methods $178,2.33-236$ (1980).

8. Volchok, H. I., Feiner, M., A Radioanalytical Laboratory Intercomparison Exercise, Report FML-365, Invironmental Measurements Laboratory, U.S. Department of Energy, New York (1979). 